\title{
Pretrial Detention of Juveniles: Denial of Equal Protection Masked by the Parens Patriae Doctrine
}

\author{
Claudia Worrell
}

Each year, almost 900,000 minors in the United States are detained in various types of adult and juvenile facilities after arrest but before any determination of guilt. ${ }^{3}$ This detention severely disrupts these juveniles' lives by separating them from their families, schools, and communities, and by subjecting them to harsh and often dangerous conditions. ${ }^{2}$ For the majority of these minors who present no serious threat to the communities from which they are exiled, ${ }^{3}$ such potentially harmful incarceration appears unjustifiable. In its recent consideration of a typical juvenile pretrial detention statute, however, the Supreme Court was able to swallow this troubling lack of correlation between detention and dangerousness with the help of a sweetening rationale: The statute affects only juveniles. ${ }^{5}$

1. Cunningham, Preventive Detention Law Seen as Setback for Youth and Blow to Science, AM. Psychological A. MonrtoR, Nov. 1984, at 36. This estimate is based on 1979 data, the most recent year for which statistics are available. Id.

2. "[T]he conditions in which [juveniles] are kept are often like something out of Dickens,' says Mark Soler, executive director of the Youth Law Center in San Francisco. 'Small, dark cells. Little human contact. Hours of boredom and depression. And, in the worst cases, physical abuse by jail staff and other inmates." "Press, When Children Go To Jail, NewsweEk, May 27, 1985, at 87 (describing problems that occur when juveniles are held in adult jails). The risk of physical and emotional harm to detained juveniles, particularly those held in adult jails, is real. To choose only a few examples from a long list: In 1982 in Boise, Idaho, a seventeen-year-old boy was tortured and murdered by his cellmates when he was detained for owing $\$ 73$ in traffic tickets; in West Virginia, a juvenile being held for truancy was murdered by an adult cellmate; in an Ohio jail, a girl was raped by a guard. Id. It cannot be assumed, however, that these minors are simply too dangerous to be placed in juvenile facilities. One recent study found that only $14 \%$ of the minors detained before trial in adult jails were accused of serious offenses. 1 Office of Juvenile Justice and Delinquency PRevention, U.S. Department of Justice, Jarl Removal Cost Study 11 (1982). A "serious offense" was defined as criminal homicide, rape, mayhem, kidnapping, aggravated assault, robbery, larceny, felonious theft, motor vehicle theft, burglary, breaking and entering, extortion with threats of violence, and felonious arson. $I d$.

3. "The findings of fact . . . make apparent that the vast majority of Jjuvenile] detentions [in New York] advance no state interest; only rarely does the statute operate to prevent crime." Schall v. Martin, 104 S. Ct. 2403, 2431 (1984) (Marshall, J., dissenting). See also Press, supra note 2, at 87 ("Nearly all [detained juveniles in California] are charged with minor offenses; few ultimately go to jail after court proceedings. Some youths are guilty of nothing more than being abused by their parents . . . ."); Bailey, Preadjudicatory Detention in a Large Metropolitan Juvenile Court, 5 LAw \& HuM. BEHAv. 19, 39 (1981) (very little correlation between seriousness of youth's offense and likelihood of being detained).

4. The Court's sweetener, however, proves to be artificial and hazardous.

5. Schall v. Martin, 104 S. Ct. 2403, 2410-11. See infra text accompanying notes 19-26. 
Numerous commentators have convincingly argued that current juvenile detention standards are violations of the due process clause and the Eighth Amendment; ${ }^{6}$ in this Note I will criticize the underlying goals and assumptions of the juvenile justice process that have made this otherwise unconstitutional detention palatable to the courts. ${ }^{7}$

In order to uncover these powerful goals and assumptions, I will first discuss the problem of juvenile pretrial detention in the context of a broader problem-the dominant role in the juvenile courts of the parens patriae doctrine. This doctrine, based on false assumptions and impracticable aims, justifies a juvenile court process that lacks clear goals and guidelines. In regard to pretrial detention, the parens patriae doctrine erroneously assumes that minors are always incompetent, and that this supposed incompetence diminishes minors' interest in freedom from state restraint. Because the interests of the accused minor and the State often conflict, the doctrine is unrealistic in its aim to protect these two parties simultaneously.

Second, I will argue that the false assumptions and confusing aims of the parens patriae doctrine successfully conspire to deprive accused juvenile delinquents of equal protection of the laws. The State's handling of accused minors who lack parental supervision will provide a particularly clear illustration of the connection between the parens patriae doctrine and the denial of equal protection. Juveniles, those with and those without parental supervision, should enjoy equal protection of the laws, both because they are similarly situated to adults in regard to the relevant criteria, and because the parens patriae doctrine cannot adequately protect their interests.

Absence of parental supervision and need for care and protection are genuine problems that the State should address. In my final section, I will suggest how the State might approach these problems without depriving juveniles of their constitutional rights or their safety.

6. See, e.g., Guggenheim, Paternalism, Prevention, and Punishment: Pretrial Detention of Juveniles, 52 N.Y.U. L. Rev. 1064, 1069 (1977); Comment, The Supreme Court and Pretrial Detention of Juveniles: A Principled Solution to a Due Process Dilemma, 132 U. PA. L. Rev. 95 (1983); Comment, A Due Process Dilemma: Pretrial Detention in Juvenile Delinquency Proceedings, $11 \mathrm{~J}$. Mar. J. Prac. \& Proc. 513 (1978).

7. I will concentrate on the equal protection problems engendered by the influence of the parens patriae doctrine on juvenile pretrial detention statutes. This is not to minimize, however, the numerous other problems with these statutes and their application that need attention. These problems include: 1) that pretrial detention often serves as punishment without proof of guilt; 2) that it stigmatizes the juvenile, robbing him or her of the opportunity to produce evidence at trial of responsible family or school behavior in the interim between arrest and trial; 3 ) that it occurs under dangerous conditions; and 4) that it interferes with preparation of a defense. 


\section{The Parens Patriae Doctrine}

In its parens patriae ${ }^{8}$ role in the Juvenile Court, the State has two professed aims: to provide guidance and rehabilitation for the child, and to provide protection for society. ${ }^{9}$ The first, "rehabilitative," aim has traditionally justified the procedural disparity between juvenile courts and adult criminal courts. ${ }^{10}$ That is, in exchange for a minor's relinquishment of due process and other constitutionally protected rights, the Juvenile Court promises to act in the minor's best interest rather than to punish him or her. ${ }^{11}$ Because the court promises to be committed to the minor's best interest, there is-the argument goes-no need for the State and the minor to take adversarial postures, ${ }^{12}$ and thus no need for the court to be hampered by the due process protections constitutionally required in an adult system.

The statutes governing when to detain accused persons before trial are much broader and less precise for minors than they are for adults. ${ }^{13}$ Thus,

8. 'Parens patriae, literally 'parent of the country,' refers traditionally to the role of the state as sovereign and guardian of persons under a legal disability to act for themselves such as juveniles, the insane, or the unknown." W. Va. v. Chas. Pfizer \& Co., 440 F.2d 1079, 1089 (2d Cir. 1971). The doctrine originated in the ancient duty of the English sovereign to protect all children within his or her realm, a duty which included the right of control over the estates of infant and incompetent heirs. See Note, The Parens Patriae Theory and Its Effect on the Constitutional Limits of Juvenile Court Powers, 27 U. PIrT. L. Rev. 894, 894-95 (1966). In the late 1800's, the doctrine became the primary justification for the establishment of juvenile courts in the United States. See Brenner, Disobedience and Juvenile Justice: Constitutional Ramifications of Childhood as a "Moral" Concept, 21 J. FAM. L. 457, 466 (1982-1983).

9. See Kent v. United States, 383 U.S. 541, 554 (1966).

10. D.B. v. Tewksbury, 545 F. Supp. 896,906 (D. Or. 1982) ("It is . . fundamentally fair-constitutional-to deny children charged with crimes rights available to adults charged with crimes if that denial is offset by a special solicitude designed for children."); In re Holmes, 379 Pa. 599, 605, 109 A. 2d 523, 525 (1954) ("[S]ince ... Juvenile Courts are not criminal courts, the constitutional rights granted to persons accused of crime are not applicable to children brought before them ....") (emphasis in original), cert. denied, 348 U.S. 973 (1955).

11. P. HahN, The Juvenile OfFender and the LAw 7 (3d ed. 1984). For criticism of this theory in the context of commitment to a mental hospital, see O'Connor v. Donaldson, 422 U.S. 563, 589 (1975) (Burger, C.J., concurring) ("Nor can I accept the theory that a State may unlawfully confine an individual thought to need treatment and justify that deprivation of liberty solely by providing some treatment. Our concepts of due process would not tolerate such a "tradeoff."'). See also Schultz \& Cohen, Isolationism In Juvenile Court Jurisprudence, in PURSUING Justice fOR THE CHILD 20, 39-40 (M. Rosenheim ed. 1976) (advocating replacement of "exchange theory," which is guided by good intentions, with principles guided by interest at stake).

12. See In re Gault, 387 U.S. 1,15-16 (1967) (Juvenile Court has attempted to cast aside "apparent rigidities, technicalities and harshness" of rules of criminal procedure in exchange for flexibility, cooperation, and parental concern of juvenile judge).

13. See Gal. Penal Code $\$ 1270(a)$ (West 1982):

(a) [A] defendant who is in custody and is arraigned on a complaint alleging an offense which is a misdemeanor. . . shall be entitled to an own recognizance release unless the court makes a finding upon the record that an own recognizance release will not reasonably assure the appearance of the defendant as required. In such event the court shall then set bail and specify the conditions, if any, whereunder the defendant shall be released.

See also ILL. Rev. STAT. ch. 38, § 110-2 (1981):

Release on Own Recognizance. When from all the circumstances the court is of the opinion that the accused will appear as required either before or after conviction the accused may be 
the state agent ${ }^{14}$ is left with great discretion to determine which accused juveniles to detain. ${ }^{15}$ The decision that arises from the exercise of this discretion is difficult to challenge, moreover, because it is assumed to have been motivated by the benevolence of the parens patriae philosophy. The "best interests of the child" tone of this philosophy, therefore, masks the inevitable competition in a juvenile court between the State's interest in community protection and the juvenile's interest in freedom from state institutional restraint.

In addition to relying on the belief that the often conflicting interests of the community and of an accused juvenile can simultaneously be protected by the State in a "flexible," "non-adversarial" system, the parens patriae doctrine relies on an assumption that minors require a greater degree of care and protection, and thus a lesser degree of liberty, than do adults. ${ }^{16}$ In contrast, my argument that minors should enjoy equal protection of the laws rests on a presumption that, at least when the State seeks to exercise

released on his own recognizance.

In contrast to adult statutes, juvenile pretrial detention statutes tend to be vague and inclusive, justifying the detention of almost any minor for a broad variety of reasons, including those that do not rest on the minor's having violated any law. For a representative example, see the Ohio statute, which states:

A child taken into custody shall not be detained or placed in shelter care prior to the hearing on the complaint unless his detention or care is required to protect the person and property of others or those of the child, or because the child may abscond or be removed from the jurisdiction of the court, or because he has no parents, guardian, or custodian or other person able to provide supervision and care for him and return him to the court when required, or because an order for his detention or shelter care has been made by the court pursuant to this chapter.

OHo Rev. Code ANN. § 2151.31(D) (Page 1974). An informal detention hearing must be held "not later than seventy-two hours after he is placed in detention, to determine whether detention or shelter care is required." Ohio Rev. Code ANN. \$ 2151.314 (Page 1977).

Similarly, the Georgia statute provides:

A child taken into custody shall not be detained or placed in shelter care prior to the hearing on the petition unless:

(1) His detention or care is required to protect the person or property of others or of the child;

(2) The child may abscond or be removed from the jurisdiction of the court;

(3) He has no parent, guardian, or custodian or other person able to provide supervision and

care for him and return him to the court when required; or

(4) An order for his detention or shelter care has been made by the court pursuant to this chapter.

GA. CODE ANN. § 15-11-18 (1985).

14. The parens patriae doctrine does not specify which state agents may exercise the State's "parental" power. Therefore, the broad discretion to decide whether or not to detain an accused juvenile may be exercised not only by judges, but also by police officers, court referees, intake officers and probation officers, depending upon the state. Sosin \& Sarri, Due Process-Reality or Myth?, in Brought To Justice? Juveniles, The Courts, And The Law 176, 189-190 (R. Sarti \& Y. Hasenfeld eds. 1976).

15. Guggenheim, supra note 6, at 1069.

16. Although "care and protection" and less liberty do not have to be viewed as inextricably linked, the Court in Schall did see the two as tied. "[T]he juvenile's liberty interest may, in appropriate circumstances, be subordinated to the State's 'parens patriae interest in preserving and promoting the welfare of the child." 104 S. Ct. at 2410 (quoting Santosky v. Kramer, 455 U.S. 745, 766 (1982)). 
its coercive power to detain, minors have as great an interest in freedom as do adults.

\section{The LIBERTy INTEREST}

The Supreme Court has said that the "involuntary confinement of an individual for any reason[] is a deprivation of liberty which the State cannot accomplish without due process of law." ${ }^{17}$ Unless we assume that minors have a lesser interest in liberty than do adults, the question of whether the pretrial detention of an accused juvenile is constitutional requires that the juvenile's interest in freedom from institutional restraint be weighed against the State's interest in protecting the community. The State's interest in detaining an arrested individual and thus protecting the community from crime is traditionally measured on the basis of factors such as the likelihood that the accused will appear at trial, and his or her level of dangerousness. ${ }^{18}$

When it recently evaluated the constitutionality of a juvenile pretrial detention statute, however, the Supreme Court did not weigh the State's interest in detaining the juveniles against the juveniles' own interests in liberty. Rather, the Court side-stepped this important investigation, and invoked the paternalism of the parens patriae doctrine to minimize accused juveniles' interests in being free from institutional restraint. In Schall v. Martin, ${ }^{10}$ the Supreme Court upheld a New York statute that authorized the pretrial detention of any accused juvenile delinquent for whom there is found to be a "serious risk" that he or she "may before the return date commit an act which if committed by an adult would constitute a crime."20 In upholding this particularly standardless and inconsistently applied statute, ${ }^{21}$ the Supreme Court approved the pretrial deten-

17. O'Connor v. Donaldson, 422 U.S. 563, 580 (1975) (Burger, C.J., concurring).

18. See, e.g., Cal. Penal Code $\S 1270(a)$ and Ill. Rev. Stat CH. 38, § 1109-2, supra note 13. This Note will not discuss the merits of pretrial detention on the basis of dangerousness or likelihood of failure to appear for trial. These factors are presented only as arguably reasonable, situationspecific measures of the State's interest in protecting the community.

19. 104 S. Ct. 2403 (1984).

20. N.Y. Jud. Acrs $\$ 320.5(3)$ (b) (McKinney 1983).

21. The lower court found that New York's statute was inconsistent both on its face and in practice. Problems apparent on the face of the statute were that:

The potential crimes [to be prevented by detention] are not limited to felonies or violent crimes but include every act which constitutes a crime under the New York Penal Law. The statute itself offers no procedural safeguards and does not set out substantive criteria, other than the conclusory "serious risk" test, such as prior court contacts or lack of family supervision, to limit which accused juveniles may be detained.

Martin v. Strasburg, 689 F.2d 365, 368 (2d Cir. 1982) (footnotes omitted), rev'd, 104 S. Ct. 2403 (1984). The paradoxical result in practice was found to be that "the vast majority of juveniles detained under 739(a)(ii) either have their petitions dismissed before an adjudication of delinquency or are released after adjudication." Id. at 369. 
tion of almost any accused juvenile, including first ${ }^{22}$ and minor $^{23}$ offenders. ${ }^{24}$

The mainstay of the Court's decision in Schall was an argument that because most juveniles are in parental custody, and because society generally approves of this fact, preadjudicatory juveniles have less of an interest in freedom from state institutional restraint than do preadjudicatory adults. ${ }^{25}$ The Court explained, "if parental control falters, the State must play its part as parens patriae."28

The Court's logic in Schall is seriously flawed for three reasons: 1) it falsely equates parental and State custody; 2) it fails to acknowledge the limits placed upon parents' license to infringe upon their children's constitutional rights; and 3) it fails to respect the limits placed upon the State in other parens patriae contexts. These errors are concealed by the apparently benevolent cloak of the parens patriae doctrine, which, in its effort to be non-adversarial, distracts participants and commentators from the very significant conflicts of interest which must be resolved, either directly or covertly, when deciding whether to detain an accused minor.

\section{A. The Difference Between Parental and State Custody}

Inherent in the Court's main argument-that a juvenile's liberty interest is weakened by the fact that he or she is already in parental custody-is a false analogy between State and parental custody. Although it is certainly true that most juveniles enjoy less liberty than do most adults, partly because of the constraints placed upon juveniles by their parents, this permissible parental constraint of liberty does not transfer intact to the State. There are three reasons why a juvenile retains in the face of a state challenge many of the liberty interests that he or she might give up to a parent: 1) there is a unique bond between parent and child; 2) there is a conflict of interest in the State's role as parens patriae that is not

22. "The case histories in the record reveal instances of detention under 739(a)(ii) of first offendcrs." Id. at 368 n.16.

23. "[O]ffenses such as playing of three-card monte can, and, as the record reveals, sometimes do trigger the sanction of 739 (a)(ii)." Id. at 368 n.15.

24. Prosecutors' fear of invoking test litigation has historically been an important deterrent to the frequent use of adult pretrial detention. See S. Saltzburg, American Criminal Procedure: Cases and Commentary 692 n.60 (2d ed. 1984) (citing N. Bases \& W. MCDonald, Preventive Detention In the District of Columbia: The First 10 Months (1972)). The Supreme Court's blanket approval of juvenile pretrial detention in Schall is thus likely to make prosecutors feel comfortable detaining even more accused juveniles under even less stringent criteria than they did prior to Schall.

25. "The juvenile's countervailing interest in freedom from institutional restraints, even for the brief time involved here, is undoubtedly substantial as well. But that interest must be qualified by the recognition that juveniles, unlike adults, are always in some form of custody." Schall, 104 S. Ct. at 2410 (citations omitted).

26. Schall, 104 S. Ct. at 2410. 
shared by parents; and 3) the Constitution directly limits the State in ways that it does not directly limit parents.

\section{The Unique Bond Between Parents and Children}

Courts have often recognized that the parent-child relationship is unique. ${ }^{27}$ The law has presumed that parents have the necessary life skills that young children lack, and, more importantly, that parents are motivated by "natural bonds of affection . . . to act in the best interests of their children."28 It is these natural family ties, and the affection and good will that they engender, which give parents unique authority over their children. ${ }^{29}$ But these familial ties that lead parents to act in the best interests of their children cannot be presumed to exist in the State-juvenile relationship, especially in the Juvenile Court context. In this context, the

27. The Supreme Court has deemed parents' rights to raise children so important as to be protected by the due process clause of the United States Constitution. Meyer v. Nebraska, 262 U.S. 390, 399 (1923). Numerous cases have shown deference to the parent-child relationship by striking down state attempts to overrule parents' decisions about the upbringing of their children. See, e.g., Wisconsin v. Yoder, 406 U.S. 205, 214 (1972) (State's interest in universal education, "however highly we rank it," must be balanced against "traditional interest of parents with respect to the religious upbringing of their children. . . ."); Pierce v. Soc'y of Sisters, 268 U.S. 510, 534-35 (1925) (act prohibiting parents from sending their children to private school "unreasonably interferes with the liberty of parents and guardians to direct the upbringing and education of children under their control.").

The standards on abuse and neglect of the Juvenile Justice Standards Project begin with the premise that the State should rarely interfere with the parent-child relationship: "[T]he basic value preference underlying the proposed standards [is] that childrearing should be left to the discretion of parents unless they fail to protect a child from certain harms, specified by statute. This preference is consistent not only with our historic policy of giving substantial deference to parental decision-making with regard to childrearing, but also with the great majority of statutory enactments and judicial decisions in this country." INST. JUD. ADMIN.-ABA JOINT COMM'N ON JUVENILE JUSTICE STANDards, Standards Relating to abuse and Neglect $\S 1.1$ commentary at 49 (1981). Recent Supreme Court decisions concerning the termination of parental rights have also stressed the high value placed upon the parent-child relationship. See Santosky v. Kramer, 455 U.S. 745, 747-48 (1982) (clear and convincing evidence of permanent neglect is needed to support contested termination of parental rights); Stanley v. Illinois, 405 U.S. 645, 651-52 (1972) (equal protection clause requires that unmarried fathers be granted hearing on their fitness before their children are removed from their custody). See also Alsager v. District Court of Polk City, 406 F. Supp. 10, 16 (S.D. Iowa 1975) (parents' fundamental "liberty" and "privacy" interests in maintaining integrity of family unit protected by due process clause), affd, 545 F.2d 1137 (8th Cir. 1976).

28. Parham v. J.R., 442 U.S. 584, 602 (1979). See also Smith v. Org. of Foster Families, 431 U.S. 816, 844 (1977) ("IT]he importance of the familial relationship . . . stems from the emotional attachments that derive from the intimacy of daily association . . . .").

29. See Baird v. Bellotti, 443 IJ.S. 622, 638 (1979) ("ID]eeply rooted in our Nation's history and tradition . . . is the belief that the parental role implies a substantial measure of authority over one's children."); Moore v. City of East Cleveland, 431 U.S. 494, 503-04 (1977) ("It is through the family that we inculcate and pass down many of our most cherished values, moral and cultural.") (footnote omitted); Ginsberg v. New York, 390 U.S. 629, 639 (1968) ("[C]onstitutional interpretation has consistently recognized that the parents' claim to authority in their own household to direct the rearing of their children is basic in the structure of our society."); Pierce v. Soc'y of Sisters, 268 U.S. 510, 535 (1925) ("[T]hose who nurture [the child] and direct his destiny have the right, coupled with the high duty, to recognize and prepare him for additional obligations."). See also Goldstein, Medical Care for the Child at Risk: On State Supervision of Parental Authority, 86 YALE L.J. 645, 645 (1977) ("To be an adult who is a parent is to be presumed in law to have the capacity, authority, and responsibility to determine and to do what is good for one's children.") (emphasis in original). 
juvenile and the state agent, (who might be a police officer, intake officer, referee, probation officer or judge), ${ }^{30}$ are usually strangers, with their sole contact a result of the juvenile's alleged delinquent act. If they do have an established relationship, it, too, most probably developed in the context of some alleged misconduct. The state agent, to whom the juvenile is a stranger or delinquent, is not likely to feel the same commitment to the juvenile's well-being that a parent would feel. We consequently cannot place in a state agent the same trust to act in the best interests of the juvenile that we place in parents.

Thus, at least in the Juvenile Court context, the right to constrain and direct children loses much of its justification in the transfer from parent to State. $^{31}$

\section{The State's Conflict of Interest}

The high risk that an accused juvenile's liberty interest might erroneously be infringed is partly created by a conflict between the State's two parens patriae interests: to protect the vulnerable individual, and to protect the community. ${ }^{32}$ When these two interests compete, the State may wrongly choose (either accidentally or maliciously) to further its community-protection interest at the unwarranted expense of the minor. In the worst scenario, the State may use the parens patriae doctrine to cover up a motive that neither protects the juvenile nor the community. For in-

\footnotetext{
30. See supra note 14 .

31. In a recent case upholding public school students' Fourth Amendment rights, but not interpreting those rights to protect students from school searches and seizures, the Supreme Court recognized that state agents do not take on the powers and immunities of parents when working with minors. New Jersey v. T.L.O., 105 S. Ct. 733 (1985). The Court rejected the in loco parentis defense to assertions of the Fourth Amendment because "school officials act as representatives of the State, not merely as surrogates for the parents, and they cannot claim the parents' immunity from the strictures of the fourth amendment." Id. at 741. Thus the Court retreated a bit from its heavy reliance on the parens patriae doctrine. It instead justified the intrusion into minors' Fourth Amendment rights by an argument concerning the special need for safety and order in public schools. See id. at 742-43. Similarly, in Ingraham v. Wright, the Court expressly declined to justify the use of corporal punishment in public schools by an in loco parentis argument, but instead relied on the State's own strong interest in maintaining discipline. 430 U.S. 651, 662 (1977).

32. The Supreme Court has previously acknowledged that the risk that a person's liberty might erroneously be curtailed does not disappear when the State is in its parens patriae role. See Addington v. Texas, 441 U.S. 418, 426-27 (1979) (although State in parens patriae role has legitimate interest in providing care to citizens unable to care for themselves, individual's interest in just outcome of civil commitment proceeding is so weighty that due process requires State to justify confinement by more than preponderance of evidence.).

The Court has also recognized that even well-meaning school officials are so likely to make errors when disciplining students that notice and a hearing are required before the official can suspend a student:

Disciplinarians, although proceeding in utmost good faith, frequently act on the reports and advice of others; and the controlling facts and the nature of the conduct under challenge are often disputed. The risk of error is not at all trivial, and it should be guarded against if that may be done without prohibitive cost or interference with the educational process.

Goss v. Lopez, 419 U.S. 565, 580 (1975).
} 
stance, some argue that the real reason juveniles are subject to much harsher pretrial detention statutes than are adults is that the incarceration of accused juvenile delinquents is an easy way for government officials to look like they are taking concrete measures to fight crime. ${ }^{33}$

Parents, however, do not face such a conflict of interest. An individual's primary task as a parent is to care for his or her own child, a task that might secondarily include preventing the child from harming the community. But it is clear to parents that society relies primarily upon the State, and not them, to protect the community. Thus, in dealing with troubled and troublesome youths, the State finds itself burdened with a conflict of interest that parents do not share. This conflict, and the resulting higher risk of an erroneous deprivation of liberty, indicates a need for stronger judicial safeguards in the State-juvenile relationship than might be deemed necessary in the parent-child relationship. ${ }^{34}$

\section{Constitutional Limits on the State That Do Not Apply to Parents}

The Supreme Court has often deferred to parental preferences in childrearing decisions, even when those preferences have conflicted with accepted state practices. ${ }^{95}$ The Court's deference may stem not only from respect for parents, however, but also from a constitutional imperative to limit the State's attempts to shape the development of children. ${ }^{36}$ This constitutional mandate to limit the State's power suggests that constitutional questions are raised whenever the State undertakes "substitute-

33. P. Hahn, The Juvenile Offender And The Law 195 (3d ed. 1984). Public fear of and anger towards juvenile delinquents may encourage government officials to impose harsh punishments. Rosenberg, The Constitutional Rights of Children Charged With Crime: Proposal For a Return To The Not So Distant Past, 27 UCLA L. REv. 656, 696-697 (1980).

34. "One of the purposes of imposing procedural constraints on decisions affecting life, liberty, or property is to reduce the incidence of error." Schall, 104 S. Ct. at 2431 (Marshall, J., dissenting). See also Gault, 387 U.S. at 19-20. ("Failure to observe the fundamental requirements of due process lin juvenile courts] has resulted in instances, which might have been avoided, of unfairness to individuals and inadequate or inaccurate findings of fact and unfortunate prescriptions of remedy.").

35. See Wisconsin v. Yoder, 406 U.S. 205 (1972) (Amish parents found to have right not to send their children to public secondary school); Pierce v. Soc'y of Sisters, 268 U.S. 510 (1925) (Oregon statute requiring parents to send children to public schools unreasonably interfered with religious liberty of parents); Meyer v. Nebraska, 262 U.S. 390 (1923) (statute forbidding instruction of foreign language to young children unconstitutionally interfered with parents' liberty).

36. See Burt, Developing Constitutional Rights of, in, and for Children, in PuRsuing Justice FOR THE CHILd 225, 242 (M. Rosenheim ed. 1976) (discussing different constitutional limits on state and parental powers); Goldstein, supra note 29, at 648-49 ("The law presumes the capacity and recognizes the authority of adults to parent their children in accord with their own individual beliefs, preferences, and life styles. It does not establish rules for child rearing to accord with some particular religious or scientific ideal."). See also Bellotti v. Baird, 443 U.S. 622, 638 (1979) ("[A]ffirmative sponsorship of particular ethical, religious, or political beliefs is something we expect the State not to attempt in a society constitutionally committed to the ideal of individual liberty and freedom of choice.") (emphasis in original); Pierce v. Soc'y of Sisters, 268 U.S. 510, 535 (1925) ("The fundamental theory of liberty upon which all governments in this Union repose excludes any general power of the State to standardize its children. . . .). 
parenting" activities. ${ }^{37}$ The constitutional questions are not always raised, however, when a parent undertakes the same activity. For instance, in Tinker v. Des Moines Independent Community School District, ${ }^{38}$ the Court held that school officials could not deny students the right to express their disapproval of the war in Vietnam by wearing black armbands to school. In light of recent cases, however, it seems extremely unlikely that a parent would be prohibited from preventing a child from taking such action. For instance, in Parham v. J.R., ${ }^{39}$ the Court made strong statements concerning the extent of parents' authority over children in matters of religion, education, and health care:

Simply because the decision of a parent is not agreeable to a child or because it involves risks does not automatically transfer the power to make that decison from the parents to some agency or office of the state. . . . We cannot assume that the result in Meyer v. Nebraska [which upheld parental right to have children taught German] . . . and Pierce $v$. Society of Sisters [which upheld parental right to send children to religious, rather than public school] ... would have been different if the children there had announced a preference to learn only English or a preference to go to a public, rather than a church, school. The fact that a child may balk at hospitalization or complain about a parental refusal to provide cosmetic surgery does not diminish the parents' authority to decide what is best for the child. Neither state officials nor federal courts are equipped to review such parental decisions.

Thus, because the Constitution specifically limits action by state and federal government rather than by private parties, and because the State is not as competent to supervise children as are parents, the State is limited more than are parents when it attempts to interfere with minors' constitutionally protected rights.

\section{B. Limits Placed Upon Parents}

The idea that the State in its parens patriae role can legitimately infringe upon minors' liberty interests because parents do so anyway is further weakened by limitations on parents' prerogatives to infringe upon their children's fundamental rights. For instance, a parent does not have the right to force an unmarried, minor daughter to have an abortion, ${ }^{40}$ nor

37. Burt, supra note 36 , at 242.

38. 393 U.S. 503 (1969).

39. 442 U.S. 584, 603-04 (1979) (absent finding of neglect or abuse, parents retain primary role in deciding whether to commit their child to mental hospital).

40. In re Mary P., 111 Misc. 2d 532, 444 N.Y.S. 2d 545, (N.Y. Fam. Ct. 1981). 
the absolute right to prevent her from obtaining one. ${ }^{41}$. A pregnant minor can obtain authorization from a judge who determines that, in spite of her parents' disapproval, the minor is either mature enough to make her own decision, or that an abortion would be in the minor's best interest. ${ }^{22}$ Even if the analogy between parental and state custody were valid, then, the State would still not have license to infringe without restriction upon juveniles' constitutionally protected rights.

\section{The Limits Placed Upon The State in Other Parens Patriae Contexts}

Schall was the first decision in which the Supreme Court specifically addressed the problem of pretrial detention of juveniles, but the Court has explored the limits of the parens patriae power in other contexts, such as the involuntary commitment of the mentally ill..$^{43}$ Although the Supreme Court in O'Connor v. Donaldson ${ }^{44}$ acknowledged the State's interest in providing care and protection for the mentally ill, it did not leave the State with unbridled discretion to pursue its parens patriae interest. ${ }^{45}$ Rather, the Court found that involuntary commitment to a mental institution must be justified by a legitimate state interest, and may not be accomplished without due process of law. ${ }^{46}$ These due process safeguards, the Court said, are necessary to ensure that the parens patriae power is not invoked indiscriminately. ${ }^{47}$

O'Connor illustrates that even incompetent persons' interests in freedom from unnecessary institutional restraint are substantial enough to require judicial safeguards, whether the State is exercising its police power or its parens patriae power. O'Connor points out that mental illness alone is not reason enough to confine a person; the State must have a legitimate need to confine him or her. ${ }^{48}$ Thus, treatment may be offered to those who are already lawfully confined, but does not justify the otherwise unlawful restriction of liberty. Because the State views both mentally ill persons and juveniles as incompetent, the constitutional restrictions on the State's right to invoke its parens patriae power to confine mentally ill

41. Bellotti v. Baird, 443 U.S. 622 (1979).

42. Id. See also Planned Parenthood v. Danforth, 428 U.S. 52 (1976) (state abortion regulation may not include mandatory parental consent provision).

43. O'Connor v. Donaldson, 422 U.S. 563 (1975). See also Wisconsin v. Yoder, 406 U.S. 205, 229-30 (1972) (Court prohibited State from acting in parens patriae role where State would interfere with rights of parents to direct religious upbringing of their children, and where there was no evidence of harm to children).

44. 422 U.S. 563 (1975).

45 Id. at 589 (Burger, G.J., concurring) (deprivation of liberty not justified by providing treatment).

46. Id. at 580 (Burger, C.J., concurring).

47. Id. at 583 (Burger, G.J., concurring).

48. Id. at 575, 583-84 (Burger, C.J., concurring). 
persons may apply in the juvenile area also. The State must have some justification for detaining a pretrial accused juvenile other than the suspicion that some "care," "treatment," or "protection" might do the juvenile good.

\section{EQual Protection}

The foregoing discussion argues that the parental-state custody equation is false. Although parents do retain some discretion to interfere with some of their children's liberty interests, this parental prerogative does not diminish a child's interest in freedom from state restraint, especially in the adversarial juvenile justice context, and even when the State asserts a parens patriae role. A minor's right to freedom from state institutional restraint is no less fundamental than that of an adult.

In spite of this fundamental liberty interest, the parens patriae doctrine relies on minors' presumed immaturity to justify pretrial detention standards that place greater restrictions on persons under the age of eighteen than over, and that have a particularly harsh impact on minors who appear to lack responsible parental supervision. Both of these classifications deny minors equal protection, because they rely on a factor-youth-not relevant to any state interest in infringing upon minors' fundamental right to freedom from institutional restraint.

\section{A. The Classification of Juveniles}

Under the fundamental rights branch of equal protection analysis, equal protection of the laws is denied when the government, lacking a compelling state interest, ${ }^{49}$ distinguishes in its allocation of a fundamental right between persons who are similarly situated. ${ }^{50}$ The differing allocation of a fundamental right-liberty - in juvenile and adult detention statutes escapes strict scrutiny because of the assumption that minors are not similarly situated to adults. Because juveniles are, in fact, similarly situated to adults with respect to the criteria relevant to the State's interest in pretrial detention, however, the dissimilar pretrial treatment of juveniles is a denial of equal protection. ${ }^{\text {s1 }}$

49. "Where there is significant encroachment upon personal liberty, the State may prevail only upon showing a subordinating interest which is compelling." Bates v. City of Little Rock, 361 U.S. 516, 524 (1960).

50. See Shapiro v. Thompson, 394 U.S. 618, 638 (1969) (state statute prohibiting welfare benefits to residents of less than one year infringed upon fundamental right to travel); Reynolds v. Sims, 377 U.S. 533, 568 (1964) (malapportioned legislative districts infringed upon fundamental right to vote); Skinner v. Oklahoma, 316 U.S. 535, 541 (1942) (as applied, statute infringed upon fundamental right to procreate).

51. The equal protection doctrine is sometimes criticized as a "back door" device used to sneak unenumerated rights and benefits under the protection of strict scrutiny. The equal protection argu- 
The most common justification for the classification of minors is their developmental immaturity ${ }^{\mathbf{6 2}}$-manifesting itself in minors' need for care, protection and guidance. ${ }^{53} \mathrm{~A}$ practical problem with basing laws on juveniles' developmental immaturity is that, as the term implies, it is not an on/off status, but a broad continuum that is correlated with age. Thus, one standard of judicial review-whether it be rational relation, strict scrutiny or some intermediate standard-may not be capable of coping appropriately with juveniles' widely varying levels of competence in the exercise of different rights. ${ }^{54}$ Ideally, one would envision a sliding-scale standard of review that would accommodate the problem of immaturity with varying degrees of intrusion according to the juvenile's actual degree of competence. ${ }^{.5}$

ment made here, however, is not subject to this criticism. Liberty is a right specifically enumerated in the due process clause of the Fourteenth Amendment, and freedom from state restraint is certainly one of the most basic forms of liberty that the due process clause was intended to protect. That liberty is so clearly protected by the due process clause makes it an appropriate object for the equal protection clause. "Probably every interest found to be fundamental and therefore protected by the due process clause will also be fundamental under the equal protection clause, so that unequal treatment with respect to that interest would be upheld only on a very strong showing of justification." Developments in the Law-Equal Protection, 82 HaRv. L. Rev. 1065, 1130 (1969).

52. Note, Assessing the Scope of Minors' Fundamental Rights: Juvenile Curfews and the Constitution, 97 Harv. L. REv. 1163, 1168 (1984). See also Schall, 104 S. Ct. at 2410 ("Children, by definition, are not assumed to have the capacity to take care of themselves. They are assumed to be subject to the control of their parents, and if parental control falters, the State must play its part as parens patriae.").

53. See Bellotti v. Baird, 443 U.S. 622, 635 (1979) (State entitled to adjust legal system to account for children's needs for concern, sympathy and attention); Ginsberg v. New York, 390 U.S. 629, 639-40 (1968) (State interest in well-being of youth justifies restriction of availability of sex material to minors under seventeen); Prince v. Massachusetts, 321 U.S. 158, 165 (1944) (in interests of society to safeguard children from abuses and to provide opportunities for growth into free and independent citizens); Bykofsky v. Borough of Middletown, 401 F. Supp. 1242, 1256-57 (M.D. Pa. 1975) (court upheld juvenile curfew, stating that, "[b]ecause of their lack of mature judgment, minors are subject to the continuing control and supervision of parents or guardians until they become of age or are emancipated"), aff'd mem., 535 F.2d 1245 (3d Cir.), cert. denied, 429 U.S. 964 (1976).

An interesting analogy can be made between sex and youth discrimination. As the inescapable facts of biology have historically provided the central justification for the oppression of women, Law, Rethinking Sex and The Constitution, 132 U. PA. L. REv. 955, 957 (1984), so have the inescapable facts of young children's immaturity provided the central justification for the restriction of minors. And as the supposed need to "protect" women has functioned as a powerful means of restricting our rights and opportunities, id., so has the supposed need to "protect," "guide," and "care for" children functioned to restrict minors" rights and opportunities. The problem with sex-based or youth-based classifications is not that they create imaginary differences; there are real biological differences between men and women, and real differences in level of maturity between minors and adults. One problem is "that sex [and I would add youth], as a proxy for some functional characteristic, is often inaccurate in relation to particular individuals. More important, even when the sex [or youth] generalization is accurate in the aggregate, these generalizations tend to be self-fulfilling and oppressive to the individual who fails to fit the mold." Id. at 1007-08 (footnote omitted). The generalizations are also used to disadvantage both groups, such as when schools allocate inadequate funds for girls' athletic programs, or when youth are jailed more frequently than adults after arrest.

54. For instance, we might want to more strictly scrutinize a law banning all minors, including sixteen and seventeen-year-olds, from living alone, than we would a law banning those under the age of thirteen from doing so.

55. A version of this argument is put forth in Letwin, After Goss v. Lopez: Student Status as Suspect Classification? 29 STAN. L. REv. 627 (1977). "Any inflexible, uniform dividing line between 
Even if all minors were incompetent, however, juvenile detention standards that did not stringently protect liberty would still deny minors the equal protection of the laws. Scrutiny of a juvenile classification must not only take into account the difficult question of the juvenile's individual level of competence, but must also determine whether level of competence is relevant to the allocation of the right in question. ${ }^{86}$ Level of competence is relevant to rights that depend upon the responsible exercise of free choice, such as the right to drive an automobile, ${ }^{57}$ and that thus require the person to act without harming him or herself or others. ${ }^{58}$ Level of competence is not relevant, however, to rights that are designed to protect the individual against governmental harm, such as the right not to be imprisoned or not to have one's property confiscated without due process, or the Eighth Amendment right to be free from cruel and unusual punishment. ${ }^{59}$ Where we want to be sure that the government does not overstep its bounds, act arbitrarily or maliciously, or otherwise cause harm, our concern is not lessened if the victim is immature, of low intelligence, or irresponsible. In fact, if the victim fits any of the above categories, we may be particularly concerned to protect him or her from governmental harm, because the victim may be less able to protect him or herself, or may be more susceptible to harmful influence. ${ }^{60}$ Strict guidelines in juvenile de-

[childhood and adulthood] is of doubtful validity, furnishing too blunt a test for determining entitlement to rights. More refined analysis would produce a varying set of legal rights expanding through the successive levels of education and age." Id. at 640-641 (footnote omitted). Letwin also asserts optimistically that "[t]he law currently is adapting to developmental conceptions that see the young maturing earlier than before and, at all events, maturing at different ages for different purposes." Id. For instance, the right to obtain an abortion has not been completely prohibited to minors, but is available to those of any age who can prove to a court that they are mature enough to make this decision. See City of Akron v. Akron Center for Reproductive Health, 462 U.S. 416 (1983) (striking down abortion ordinance restricting abortions for women under age fifteen because ordinance did not expressly provide opportunity for case-by-case evaluation of maturity); Bellotti v. Baird, 443 U.S. 622 (1979); Planned Parenthood v. Danforth, 428 U.S. 52 (1976).

56. Letwin, supra note 55, at 642.

57. For example, one's level of competence might arguably be related to the following rights which are sometimes restricted to adults: the right to enlist in the military, to contract, to purchase or consume alcohol, to vote, to work in certain jobs, and to marry without parental consent.

58. Letwin, supra note 55, at 641-42. See also Hafen, Children's Liberation and the New Egalitarianism: Some Reservations About Abandoning Youth to Their "Rights," 1976 B.Y.U. L. REv. $605,644-48$ (1976) (arguing in favor of Supreme Court's recent extention of "rights of protection" to children, but against removal of constraints upon children's "rights of choice").

59. Letwin, supra note 55, at 642.

60. For instance, in W. Va. State Bd. of Educ. v. Barnette, the Court was particularly concerned about protecting juveniles from unconstitutional government restriction of their right to free speech, because this restriction might have a harmful effect upon their development.

The Fourteenth Amendment, as now applied to the States, protects the citizen against the

State itself and all of its creatures-Boards of Education not excepted. . . . That they are educating the young for citizenship is reason for scrupulous protection of Constitutional freedoms of the individual, if we are not to strangle the free mind at its source and teach youth to discount important principles of our government as mere platitudes.

319 U.S. 624,637 (1943). The Court concluded that it was an unconstitutional infringement of public school children's right to free speech for the State to make it compulsory for them to salute the flag 
tention standards would protect juveniles from erroneous and dangerous detention, a consequence that is surely not rendered inappropriate by some juveniles' developmental immaturity.

The absence of strict guidelines in juvenile detention standards burdens only minors, yet is not related to the justification for differentiating them from adults-their sometimes lower level of competence. Thus the parens patriae doctrine's emphasis on a minor's possible incompetence masks the denial of equal protection by focusing discussion on a distinction that is irrelevant to the constitutional protection in question.

\section{B. Availability of Parental Supervision}

Juvenile courts' treatment of accused minors who lack parental supervision highlights the link between the parens patriae doctrine and unconstitutional detention. Because the parens patriae doctrine is triggered by an individual's need for care and protection, the doctrine has particularly harsh effects on those arrested juveniles whose parents are (or are suspected to be) unwilling or unable to supervise them until trial. This phenomenon is a key part of the juvenile detention problem: Many juveniles are detained solely because they lack a parent willing to take them home. ${ }^{61}$ Detention on the basis of inadequate parental supervision is a denial of equal protection not only because it is based on an irrelevant assumption of incompetence, but also because the remedy chosen-detention-is not adequately tailored to the problem of parental absence.

and pledge allegiance.

61. A study of a Denver, Colorado juvenile detention center found that over one-third of the minors referred to the center did not pose any danger or risk to the community, but were referred exclusively because their parents were unavailable or because of family problems. Reducing SECURE Juvenile Detention: Jefferson County Juvenile Detention Genter, Louisville, Kentucky and Arapahoe County Juvenile Detention Genter, Denver, Colorado 5 (1980) [hereinafter cited as Reducing Secure Juvenile Detention]. A literature search by the United States Government concluded that the high rate of detention of accused status offenders was correlated with lack of family willingness or ability to assume custody. See 2 OFFICE OF JUVENILE JUSTICE AND Delinguency Prevention, National Juvenile Justice Assessment Centers, A National assessment of Case Disposition and Glassification in the Juvenile Justice System: InCONSISTENT LABELING 125 (April 1980) [hereinafter cited as INCONSISTENT LABELING].

"[Y]outh who have no home or whose parents refuse to accept them run the highest risk of detention regardless of what they have or have not done." Sarri, Service Technologies: Diversion, Probation, and Detention, in Brought To Justice? Juveniles, The CourTs, and The Law 151, 167 (R. Sarri \& Y. Hasenfeld eds. 1976).

Some juveniles are placed in jail specifically and only because their parents want them to be, even though these juveniles pose no threat whatsoever to the community. In 1982, a fifteen-year-old Kentucky boy hanged himself while jailed for arguing with his mother. An Idaho boy, jailed at the request of his parents in the hopes of "scaring him straight," was tortured and murdered by his cellmates in 1982. Press, supra note 2 , at 89. 


\section{An Inappropriate Remedy}

To infringe upon a fundamental right, the government must show not only that it has a compelling state interest, but also that the means chosen is necessary to further this interest. ${ }^{62}$ Like immaturity, the absence of parental care and supervision seems closely related to the decision to place an arrested juvenile in pretrial detention. Closer inspection, however, reveals that the fit between the State's goal of providing substitute parental supervision and its chosen method of pretrial detention is unacceptably imprecise. Although absence of parental care is a problem to be addressed by the State, it is not a problem that in and of itself necessitates, or even indicates, coercive detention by the Juvenile Court. An accused minor's need for care should be separated from the court's decision whether or not to exercise its police power and detain the minor as part of the juvenile justice process. ${ }^{\mathrm{es}}$

\section{Distinguishing Between Child and Parental Misconduct}

The practice of incarcerating minors who lack responsible parental supervision offends our sense of justice for another reason. If the primary problem with the disposition of these cases is the lack of a responsible parent, the minor is being incarcerated because of the parent's misconduct rather than because of his or her own conduct. ${ }^{\text {B4 }}$ The Supreme Court has recently declined to inflict punitive measures against children for their parents' illegal conduct. In Plyler v. Doe ${ }^{68}$ the Court declared that "legislation directing the onus of a parent's misconduct against his children does not comport with fundamental conceptions of justice." ${ }^{38}$

62. See McLaughlin v. Florida, 379 U.S. 184, 192-93, 196 (1964).

63. The Supreme Court has found that procedures that make it easier for the State to deprive a mentally ill person of his or her liberty because of charges pending against him or her violate the equal protection clause. See Jackson v. Indiana, 406 U.S. 715, 729-30 (1972). Just as it violates equal protection principles for the State to institutionalize mentally ill persons possibly in need of care on the basis of pending criminal charges, it also violates equal protection principles for the State to detain accused juvenile delinquents on the basis of a possible need for care and protection.

64. See Inst. Jud. Admin.-ABA Joint Comm'n on Juvenile Justice Standards, Standards Relating to Interim Status: The Release, Control, and Detention of Accused JuVEnile Offenders Between ARRest AND Disposition § 3.3(B) (1980) (pretrial detention should never be used to allow parents to avoid their legal responsibilities).

65. 457 U.S. 202 (1982) (no substantial state interest in denying free public education to children who are illegal aliens).

66. Id. at 220. In cases deciding what to do about the absence of parental care and supervision, the tradition of protecting children's rights through their parents' rights leaves the child extremely vulnerable. For an example of this tradition, see Wisconsin v. Yoder, 406 U.S. 205 (1972), where, rather than declaring that Amish children should be allowed free exercise of their religious beliefs and not be made to forsake them by attending public high school, the Court relied upon the parental prerogative to direct the upbringing of one's children in order to justify exempting the children from Wisconsin's compulsory school-attendance law. Id. at 213-15, 230-32. Justice Douglas, however, dissented in part on the ground that only the child's own religious freedom should be protected, not the parent's. Id. at 241-46. 


\section{Separating The Interests of The Juvenile and The State: A SteP Toward EQUal Protection}

An underlying problem in the area of juvenile law is the lack of clear goals motivating the juvenile justice system. ${ }^{67}$ This general confusion within the system makes it difficult for state agents to agree upon a clear purpose for the specific practice of juvenile detention, and thus even more difficult to agree upon criteria for imposing this detention. ${ }^{68}$ The "benevolent" motives of the parens patriae doctrine presently function as the fallback justification for juvenile courts' actions, but the doctrine itself is the quintessential example of the overall confusion within the system. Because the system cannot agree on a primary goal, the doctrine must profess the impossible: that the Juvenile Court can, in each case, make a decision that protects both the accused juvenile and the State. In many cases, however, the parties' interests are mutually exclusive, and the Juvenile Court must therefore choose which interest to protect. When it chooses to protect the State's interest and infringe upon that of the minor, the Juvenile Court glosses over its choice by emphasizing the "parental" nature of the State's

67. The system is plagued by conflicting demands-to protect the juvenile, yet to assure his or her presence at trial, and to prevent crime. Mulvey \& Saunders, Juvenile Detention Criteria: State of The Art and Guidelines For Change, Griminal Justice ABstracts 261, 264 (1982). Detention criteria thus range from "vague and inclusive" to "specific and limiting," depending on whether the jurisdiction adheres more strongly to a parens patriae or due process philosophy. Id. at 263-64. See also M. Sosin, Parens Patriae And Dispositions in Juvenile Courts 25 (Inst. for Research on Poverty Series No. 496, 1978) ("IJuvenile courts must be characterized in terms of the complexity and diversity of their ideologies and organizational patterns.").

68. The criteria utilized to determine when to detain minors vary widely between jurisdictions. See Inconsistent Labeling, supra note 61, at 124-5. See also Sosin \& Sarri, Due Process-Reality or Myth?, in Brought To Justice? Juveniles, The Courts, and The Law 176, 190 (R. Sarri \& Y. Hasenfeld eds. 1976). In this national survey of juvenile court personnel, the following percentages of judges responded "always" or "often" to whether they used the following criteria in their pretrial detention decision:

\section{CRITERIA}

1. Protection of juvenile

2. Protection of community

3. Probable cause related to allegation

4. High risk that juvenile will abscond

5. Nowhere else to send youth

6. Preventive detention
Percent of Judges RESPONDING "ALWAYS" OR "OFTEN"

$70 \%$

$66 \%$

$48 \%$

$43 \%$

$24 \%$

$22 \%$

There is evidence that those minors accused of the least serious offenses-status offenses-are more likely to be detained than are minors accused of some actual crimes. A status offense is an act considered illegal only if done by a minor: Running away, truancy, curfew violations, and ingovernability are a few. Kramer and Steffensmeier, The Differential Detention / Jailing of Juveniles: A Comparison of Detention and Non-Detention Courts, 5 PEPPERDINE L. REv. 795, 804 (1978). Using data from forty-five Pennsylvania county courts in 1973-1975, the authors found that females accused of status offenses were particularly likely to be detained. Id. See also Bailey, supra note 3 (very little correlation between seriousness of youth's offense and likelihood of being detained). 
actions and the intrinsic incompetence of minors. Thus, the use of the parens patriae rationale may function as a signal that the State is unjustly infringing upon a minor's fundamental liberty interest; if the State had a compelling community protection interest, the Juvenile Court could be explicit in its reasons for detaining the minor. ${ }^{68}$ In order to prevent the ingenuous use of the "best interests of the child" rationale, the Juvenile Court should abandon the parens patriae justifications for pretrial detention and adopt an approach that keeps due process and caretaking concerns separate. ${ }^{70}$

The Juvenile court must first divide the question of what to do with an arrested juvenile into two steps. The first step, whether to detain the juvenile, should be motivated by the State's community protection interests, but should not be influenced by the State's goals of care and protection. The decision during this first step should not be left in the state agent's discretion, but should be guided by specific criteria delineating when it is proper to detain a juvenile for the community's protection. ${ }^{71}$ Specific, limiting guidelines have been introduced in some jurisdictions, with the result of dramatically reduced detention and no increased danger to the community. ${ }^{72}$

69. Although it is preferable to base intrusions into a person's constitutionally protected rights on the gravity of the State's need rather than on a person's less powerful position in society, this approach is not immune from abuse. If the State is determined to infringe upon a person or group of persons' constitutionally protected rights, it can always argue that its interest is compelling. In its efforts to limit minors' rights, the Supreme Court may, in fact, be moving in this dangerous direction. In New Jersey v. T.L.O., 105 S. Ct. 733 (1985), the Court upheld the search of a student by a school official not on grounds of the State's parens patriae role, nor on grounds that minors have weaker fourth amendment rights than do adults, but on the arguable grounds that the State has an especially strong interest in maintaining safety and order in schools. See also Ingraham v. Wright, 430 U.S. 651, 662 (1977) (use of corporal punishment in public schools justified not by in loco parentis argument, but by State's own need for education and group discipline in schools).

70. Such a process would not only better protect minors' liberty interests, but would also better serve community protection purposes. If accused criminals view the judicial process as irrational or unjust, they may reject any moral condemnation and view the risk of punishment as merely an "occupational hazard." See Seidman, Soldiers, Martyrs, and Criminals: Utilitarian Theory and The Problem of Crime Control, 94 YALE L.J. 315, 347 (1984). This concern seems particularly relevant to the Juvenile Court, the stated goal of which is not to punish, but to prevent young people's problems, including altercations with the law, from leading to criminal careers. Juveniles learn about the law and society's expectations of them from any involvement they have with the police and the juvenile courts. In order for a juvenile to be deterred from committing more crimes, he or she must perceive his or her punishment as being just-both with respect to the offense committed, and with respect to the punishments being received by others. By detaining juveniles in a haphazard and unprincipled manner, the Juvenile Court is itself partially responsible for some juveniles' attitudes that the risk of punishment is merely a hazard that does not inspire any remorse or deterrence.

71. "Opportunities for improvement in the [New York juvenile detention] regime are apparent even to a casual observer. Most obviously, some measure of guidance to Family Court judges regarding the evidence they should consider and the standard of proof they should use in making their determinations would surely contribute to the quality of their detention determinations." Schall, 104 S. Ct. 2403, 2431 (1984) (Marshall, J., dissenting).

72. One study comparing secure and non-secure juvenile detention found that less than $13 \%$ of juveniles in programs providing alternatives to secure detention committed new offenses or ran away. D. Pappenfort \& T. Young Use of Secure Detention for Juveniles and Alternatives to 
The second step, what to do with juveniles who are not eligible for detention, may properly be influenced by an absence of parental supervision or other need for the State's care. At this stage, however, the juvenile should be treated no differently than non-arrested juveniles who lack adequate parents, and should thus be placed in a care-oriented, non-secure foster or group home. ${ }^{73}$ In order to prevent the inappropriate use of this second step, the same legal procedures should be required as when the State takes custody of any child. That is, children literally without parents should be taken into temporary State custody while a search is instituted for their parents, and children who appear to be without "adequate" parental care should only be taken into custody if proceedings of neglect, abuse or abandonment are begun against the parents.

\section{ConcLusion}

The lack of specific criteria guiding decisions to detain juveniles before trial, which in an adult court would be viewed as a denial of due process, is commonly justified by the Juvenile Court's "benevolent," parens patriae philosophy. This philosophy, however, falsely assumes that minors have a lesser interest in freedom from state institutional restraint than do

ITS UsE 88 (1980). See also infra note 73.

73. At the Jefferson County Juvenile Detention Center in Louisville, Kentucky, specific criteria were instituted that restricted detention to youths who met at least one of the following criteria:

1. Youth who are charged with Class A and B felonies, except Burglary I. These felonies are: Murder, Manslaughter I, Assault I, Kidnapping, Rape I, Sodomy I, Arson I, and Robbery $\mathrm{I}$.

2. Youth who are charged with their second felony (or more) within the previous 60 days.

3. Youth with an outstanding Bench Warrant.

4. Youth who are charged with Escape, any degree.

5. Youth ordered remanded by Court/Judge.

6. Youth from out-of-county charged with felonies.

7. Youth who are charged with their second (or more) offense, either felony or misdemeanor, within the previous 45 days-THIS DOES NOT APPLY TO VIOLATIONS [offenses punishable by fine only] OR STATUS OFFENSES.

Reducing Secure Juvenile Detention, supra note 61 , at 9.

Before implementation of the strict criteria, $42.2 \%$ of all youths who were referred to intake were held in excess of twelve hours. Six months after implementation, however, only $23.4 \%$ of those youths who were referred to intake were held longer than twelve hours. Id. at 3 . The increase in the number of youths who were released to non-secure settings did not result in a statistically significant increase in total re-arrests or felony arrests within 80 days. Id. at 4 . Although there was an increase in the rate of failures-to-appear in court, all but one of those youths who had been charged with a felony had been located by February, 1980. Id. at 4-5. "Therefore," the authors concluded, "the implementation of strict criteria presented no significant threat to either public safety or the court process." Id. at 5.

Implementation of similar criteria at the Arapahoe County Juvenile Detention Center in Denver, Colorado also had very positive results. During the year before implementation of strict criteria, the intake unit detained $86 \%$ of youths referred to it; in the year after implementation, however, the unit held only $69 \%$. Id. at 6 . The intake unit also found that continuous monitoring of the juveniles allowed it to release significantly more youths earlier. The number of youths released within 24 hours jumped from $25 \%$ to $50 \%$, and the number released within 48 hours jumped from $25 \%$ to $66 \%$. Id. at 6 . In spite of the increased release rate, the county experienced no statistically significant rise in new delinquency petitions, rearrests, or failures-to-appear in court after 90 or 180 days. Id. at 7 . 
adults, and thus leads to a denial of equal protection. Because the handling and disposition of juvenile cases often requires a choice between conflicting state and individual interests, the Juvenile Court is not a purely benevolent force, but necessarily a coercive one also. The parens patriae philosophy attempts to disguise the frequent supremacy of the State's interest, but the Juvenile Court would do better to acknowledge openly the power of the State, and to provide safeguards that take that sometimes coercive power into account. The reality that a juvenile court often must choose between conflicting interests should openly be acknowledged and accounted for through the adoption of specific guidelines, rather than obscured under the parens patriae doctrine's gloss of "care and protection." 
